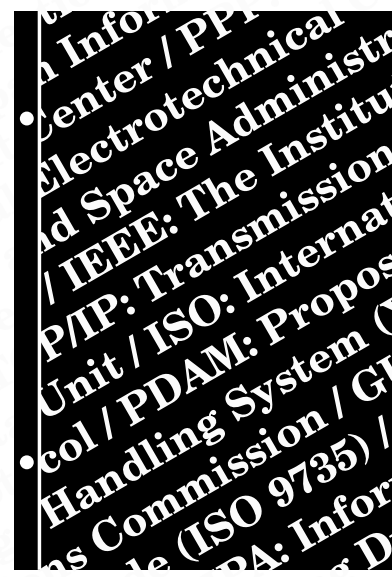

標準化現場ノート 第 6 回

\title{
JPEG 2000
}

キーワード : JPEG 2000, ISO/IEC JTC 1/SC29/WG1，ITU-T，標準化

(正会員) 小野文 孝

\section{1.まえがき}

JPEG 2000は, ISO/IEC JTC 1/SC29/WG1で, 21 世紀の標準として2000年の年末に標準化され，現在 もAMD (Amendment : 追補) の作成などの活動が続いて いる静止画符号化方式である. JPEG 2000に先立つ静止 画像の国際標準符号化としては，G3FAXの2次元符号化， JPEG (Joint Photographic Experts Group), JBIG (Joint Bi-level Image Experts Group)などがある. JPEG 2000標準化をそれらと比較すると, 会議の参加者 数では恐らく最大であったこと, 提案方式の数も同様に最 大であったことがその特徵といえる1)。つまりJPEG標準 の成功を受け，その後継という位置づけに大きな期待が集 まったわけである. また, 多くの提案がありながら, 標準 化を当初の目標期日に間に合わせることができたのは特筆 すべきことであった，しかし，一方では，標準化後の普及 が必ずしも期待通りではなく，関係者を悩ませることにも なった. 以下では, 他の静止画符号化標準化の歴史も踏ま えて, JPEG 2000の標準化を振り返り, 同時に今後の標 準化のあり方についても考えてみたい

\section{JPEG 2000誕生の背景と経緯}

画像は大きく2值画像, カラ一静止画像, 動画像に分か れ，画像のディジタル化はこの順で普及してきた．2值画 像の国際標準符号化については，1980年にファクシミリ のG3規格の標準化の形で達成され，記録画像通信である ファクシミリ市場が急速に拡大した，それとともに，情報 文書をファクシミリで送信するサービスの検討も始まっ た. しかし，このようなサービスの先にはソフトコピー通 信としてのデータベース検索が必須であり，それを担うも のとしてビデオテックスが注目を浴びるようになった

ビデオテックスの国際標準化では, 日米欧から3種の方式 (CAPTAIN, NAPLPS, CEPT)が提案され，1984年にそ

†東京工芸大学 工学部

"JPEG 2000" by Fumitaka Ono (Faculty of Engineering, Tokyo Polytechnic University, Tokyo)
の3方式が併存する形で国際標準に採用された。これは当 時の状況としては，ある意味でやむを得ない選択であった． その後, フォトビデオテックスとして静止画の統一標準化 を行うことになり，当時のISO/TC97/SC2/WG8と CCITT SGVIII/NIC (New Image Communication) とが 共同作業機関JPEGを設立し，1986年に活動を開始した。 この結果作成されたのがよく知られているJPEG標準 (ITUT T.81|ISO/IEC 10918-1)である. この標準化において もやはり日米欧からの3種類の提案(GBTC, ABAC, ADCT) が残り，欧州提案であるADCT方式を基にした標準化内容 が，1980年代の終わりに実質的に定まった。

実はJPEGの標準化が決まった頃には, カラ一静止画符号 化を利用するよいアプリケーションがなく，筆者らは折角作 った標準を何とか使ってもらおうと，印刷会社・出版社に足 繁く通ったが, なかなか色よい返事が得られない状況にあっ た. とはいえ，JPEG委員会としては，将来の市場を期待し て細々とJPEGシリーズの拡張 (part2〜part4)に取組んで いた.

そうこうしているうちに，1995年に液晶モ二夕付きの ディジタルカメラが登場し，一気にディジタルカメラの市 場が広がった．また，ビデオテックスにとってかわったイ ンターネットも驚異的なスピードで普及し，さらに，ビジ ネスの社会でもディジタル化された画像が受け入れられる ようになり,JPEGは一挙にいわばオールマイティ標準と しての役目を期待されるようになってきた，そうなると， JPEGの問題点も指摘されるようになり，まずJPEGにも 規定はされているものの，ほとんど使われていなかった口 スレス符号化機能に着目した新標準の作成活動が開始され た.これがLossless Compression of Continuoustone Still Pictures (JPEG-LS : ITU-T T.87, T.870| ISO/IEC 14495)であり, '95年7月締切で提案を募集す ることになった。

一般に静止画符号化の基本技術は，DCT (Discrete Cosine Transform)などの (周波数) 变換方式と (空間) 予 測方式に大きく分かれ，前者はJPEGベースラインのよう なロッシ一符号化に，後者はロスレス符号化に適している. 




図 1 WOMAN (512×640×24) のPSNRとビットレートの関係

\begin{tabular}{|l|}
\multicolumn{1}{|c|}{ 表3 JPEG 2000の各part一覧 } \\
\hline Part1 : 基本方式 \\
Part2 : 拡張方式 \\
Part3 : Motion JPEG 2000 \\
Part4 : 相互接続試験 \\
Part5 : 参照ソフトウェア \\
Part6 : 写真・文字混在画像の符号フォーマット \\
Part7 : (欠番) \\
Part8 : セキュリティ \\
Part9 : API拉よびProtocol \\
Part10 : 3次元データ \\
Part11 : ワイヤレス \\
Part12 : MPEGとのコモンフォーマット \\
Part13 : エンコーダ \\
Part14 : XML構造の表現と参照
\end{tabular}

JPEG 2000に関するIP分科会を結成し2)，より慎重な対 応をとってきた。このような日本の慎重な姿勢は，必ずし も他国に充分理解されてきたわけではないが，part13と いう符号器規格の標準化を日本主導で行うことにより, 懸 念されていた符号化機能の特許も明確化でき, より心配の 少ない状況にできたといえる。

標準化参加者数については，最初に言及したが，JPEG 2000の方式提案が行われた1997年11月のSydney会合 の参加者は 103 人に達し，その後も方式が確定するまでは 毎回それに近い参加者があった．また，日本のメ一力のいく つかは, 海外の研究所からも技術者を現地代表として送り込 み，複数の国の意見として提案を強化する例が出てきた．こ のような多くの参加者があったのは,JPEGが国際標準の成 功例として評価され，その後継としてのJPEG 2000に大 きな期待が寄せられたことが最も大きな理由である，なお， この結果として, HOD (Head of Delegation: 各国団長)会 議,WG1プレナリー会議など, それまでWG1にはなかった 会議スタイルが取り入れられ，それは現在にも引き継がれて いる.

\section{5. 標準化に関わる技術者の方に}

画像符号化において，標準のもつ意味はきわめて大きい ものがある.これは，符号化方式を外部インタフェースに 使用する場合，他社の製品との接続には必ず標準方式を用 いる必要があり，逆に標準化に採用されないと，どんなに 優れた方式でも陽の目をみないことがあるためである。 ま た，異方式間で互換性を保つことは難しく，そのためには 複数の方式を搭載せざるを得ない，したがって，標準化に おける主導権争いは時に極めて激しいものとなる.

符号化方式を評価する上では，画質，符号量，符号復号 器の複雑度 (装置規模・処理時間)を考慮する必要がある. ロスレスであれば画質は共通になるので, 符号量と複雑度 との比較になる，ロッシーであれば符号量を固定し，画質 ない、とはいえJPEGでの苦い経験を踏まえ，国内では 
と複雑度とが検討対象になる，しかし同一方式でパラメー タが異なるような場合は別として, まったく相違する方式 同士の複雑度の比較はきわめて難しいと言わざるを得な い. JPEGにおいても結果的には杞憂に終わったが, 選考 時にはDCT方式の複雑度を懸念する意見もあった。

さて，標準化の提案者は互いに技術を争う一方で，標準 化作業の重要性を社会や所属機関にアピールしたいという 点では共通の利害関係を有している。したがって, 第1次 選考で提案方式が選ばれなかったメンバにも，技術的な検 討のため引き続き参加してもらうのが望ましい，幸い標準 の構成要素は複数あるので, 第 1 次選考で 1 位になった方 式のすべての要素をそのまま標準にするのではなく，いわ ば基準の方式として扱い，よりよい部品があれば適宜置き 換えるような開発型の進め方が採用されることが多い.こ の結果, 部品レベルでの再審査の道もあるし, インタフェ 一スを取り直して新たな方式を導入することもありうるの で, 第 1 次選考は単なる指標と考え, 最後まで参加して知 恵を出し合うことが望まれる. 実際このような手続きによ つて第1次選考の方式より最終的には格段に優れた方式が 標準となることも多い.

また，標準化で重要であるのが，アルゴリズムが定まっ た後でのコンフォーマンスやリファランスソフトウェアの 策定作業である. これらも標準の体系を構成しており，こ れらを供給することで，標準の実装を容易にしたり，普及 の広範化を図ることができる，このため，一見地味ではあ るが, このような作業は標準化にとっては極めて重要であ る. また, こうした作業の過程で記述の曖昧さや解釈の相 違が判明することも多い，標準の作成には直接携わらない つもりでも，作成された標準に治ったLSIの製作等を考え ておられる方には, ぜひこのような段階から参画していた だきたい．

また，特許の問題も標準化に大きな影響力を持つ，特に SC29/WG1では，基本的に必須機能を特許が無料の技術 で構成し，オプションでは無料でない技術も認めるという 方針を貫いている。これは特許の有料使用を前提とし，そ のための組織として MPEG LAを擁している SC29/WG 11 とは大きく異なる. 特許を無料で提供する ことには抵抗を覚える向きもあるかもしれないが, 静止画 はコンテンツがビジネスになるわけではないので, 有料に したところで他の業界からの収入は期待できず，巨視的に 見れば同じ業界の中での特許料の収受にとどまる. それよ り，各社が参入しやすくして市場を大きくし，その中で製 品やLSI等の売り上げを増やす努力をすることの方が, 企 業にとっては有益である. 実際, 標準の提案者であること は, 方式の理解にも長けているといえるので, その機関の 製品はより安心といえる.したがって, 標準化会合への提 案や参画の実績をアピールすることで, 製品のシェアを高 めることも充分できるのである.JPEG 2000が開始され
てからの参加者の中にはWG 11 と同様に, 特許での収益の みをあてにする方々も含まれていたが，このようなWG 1 の特許ポリシーや，現実的な特許活用手法を説明し，理解 いただくこととなった。

さて, JPEG 2000の基本方式の標準化からまもなく 10 年になるが，特に静止画最大の市場であるディジタル カメラにJPEG 2000を採用するメーカがまだ出ていな い.これは，すでに確固たる地位を固めているJPEGとの コスト面や処理時間の差に基づいているのは確かである. 現実には, JPEG 2000搭載カメラを現在売り出しても, JPEG 2000機能に加え, JPEG機能, もしくはJPEGへ のトランスコーダ機能の搭載を必要とする. そうなると， そのコストに見合った利点があるかどうかが問われること になる. しかしこの問題はJPEG 2000の開発時からわか っていたはずであり, 既存標準が存在する分野に新しい標 準の普及を試みることの難しさは，過去にもJBIG， MPEG-4などで経験済みである，何しろ，これだけ世界中 の英知を集めうる機会はめったにないであろうから，この 問題をもっとしっかり考えておくべきではなかったかとい う思いにもずっとかられてきた。

新標準を開発し，その搭載装置が既存の標準を搭載せず に済むためには，新しいアプリケーションの開拓が必要で あり, JPEG 2000における, その最たるものは, 現時点 ではディジタルシネマといえる. ディジタルシネマが符号 化方式にJPEG 2000を採用した大きな理由は, JPEG 2000が2K画像 (2048x 1080 ) と4K画像 (4096× 2160)のプログレッシブ表現機能を有する点である，つ まり，コスト優先で2K画像を使用している映画館に対し ても，画質優先で4K画像を使用している映画館に対して も統一フォーマットで画像が提供できるという特徵であ る. またフレーム単位での編集が可能という編集面の便利 さ，特許が無償であることも大きい，このため，現在 JPEG 2000 part1のAMDとして, ディジタルシネマ対 応のいくつかのプロファイルを追加している.JPEG 2000のアプリケーションとしては，他にも各種の公的文 書への適用が進んでいる. 国内では国立国会図書館, 国立 公文書館などで, 従来, 紙文書で保存していた文書を電子 データでも保存できるようにするためのシステムを開発中 であり，そこにはJPEG 2000が採用されている．また旧 社会保険庁の保険料支払いの証明書も, JPEG 2000を使 用して電子保存されている. また, 銀行などでのクレジッ トカードの申し込みにも，JPEG 2000の採用が進んでい る。さらに、パスポート、運転免許証などには国際的に JPEG 2000の適用が進んでいる. このような文書の量は いずれも膨大であり，圧縮効率がJPEGの2倍であれば， 記憶容量として億円単位の節約すら可能になる. このよう にJPEG 2000もようやくその応用に光明が見えてきたと もいえる. 
標準化に関わる個人的感想についても述べると,JPEG 2000の標準化については, 各国のメンバと力を合わせる ことによって技術的に高い標準を作成できたという思いが 強く，その分標準化後の普及の問題が今でもずっと気にな っている，なお，筆者の永年の標準化活動における雑多な 感想については, 文献3) およびその中での引用文献を参 照いただきたい。

\section{6. むす び}

JPEG 2000以降に成立したSC29/WG 1のプロジェク トとしては, 画像検索に関わるJPSearch (ISO/IEC 24800シリーズ), JPEGとJPEG 2000の中間的位置 づけとなるJPEG XR image coding system (JPEG XR:ISO/IEC 29199シリーズ), 画像評価の標準化とそ れに基づく符号化標準の策定を目指すAdvanced image coding and evaluation methodologies (AIC: ISO/IEC 29170 シリーズ)がある.このうち. JPSearchについては, SC29/WG 11 1のMPEG-7と協調 して進められ，現在全6partの内容がほぼ定まった。 JPEG XRは, Microsoft社がWindows Vistaでサポート している静止画符号化方式HD Photoを基本としており,
WG 1 としてのアルゴリズムの議論などはほとんど行われ ないまま短期間で標準化が達成された，その意味でAICは， 画像符号化としてはJPEG 2000以来の本格的なプロジェ クトといえるが，幸か不幸か具体的な審議はまだ始まって いない.JPEG 2000の制定から10年を迎える現在，今 後の標準化において何を基本として進めていくかについて 腰を据えて議論すべき時なのかもしれない.

(2010年7月1日受付)

\section{〔文 献〕}

1）小野·上野 · 渥美：“JPEG2000の技術動向”, 映情学誌, 52, 12, pp.1779-1784（Dec.1998）

2) 小野・河村：“画像圧縮符号化の標準化活動とIP問題に関して JPEG2000 IP分科会活動報告 - ”, 画電誌, 32, 1, pp.87-92（Jan. 2003)

3）小野：“国際標準化活動の諸課題－継続的参画経験に基づく考察”, 画電学会STD研資4-1（2009年10月）

小野 文䓔 1971年, 東京大学電子工学科卒業.
1973年, 同大学院電子工学専攻修士課程修了. 同年,
三菱電機 (株) 入社. 2000 年東京工去大学教授.
ISO/IEC JTC 1/SC 29/WG1 JBIG Rapporteur. 工学
博士. 正会員.

